\title{
Contracting Around Liability Rules
}

\author{
Mark A. Lemley*
}

In his influential paper Contracting into Liability Rules: Intellectual Property Rights and Collective Rights Organizations, Robert Merges makes the case that intellectual property (IP) owners vested with property entitlements can and do contract away their right to an injunction when it is efficient for them to do so. The result was to cement for many the superiority of property over liability rules, since Merges demonstrated a seemingly critical asymmetry between the two. Merges's evidence suggested that if a judge or a legislature got the damages calculation wrong, we were stuck with an inefficient liability rule, but that we weren't similarly stuck with an inefficiently-allocated property rule.

The evidence Merges brought to bear in his path-breaking article is extremely important. But it is incomplete. True, parties can contract around inefficient property rules in IP cases. But as I show in this Essay, they can-and do-contract around inefficient liability rules as well. The result does not prove the superiority of liability rules over property rules, but it does undermine a major premise that has been used to support the claim that IP rights must be protected by property rules.

Introduction

I. Property Rules, Liability Rules, and Contracting......

A. Property Rules and Liability Rules in IP Cases ................................ 466

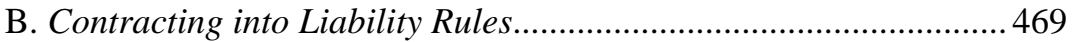

II. Contracting Around Liability Rules ......................................................... 470

A. Liability Rules in IP........................................................................ 471

B. Liability Rules, Property Rules, and Settlement in Patent Cases.... 472

1. Settlements After eBay

Copyright (C 2012 Mark A. Lemley.

* William H. Neukom Professor, Stanford Law School; Partner, Durie Tangri LLP. Articles Editor, California Law Review, 1990-91. The author would like to thank Paul Goldstein, Preston Padden, and Cary Sherman for helpful discussions of copyright licensing practices and Daniel Crane, John Golden, Paul Goldstein, Rose Hagan, Jerry Reichman, and Phil Weiser for comments on an earlier draft. 


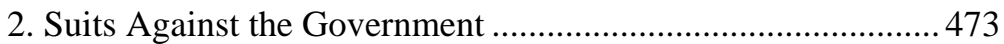

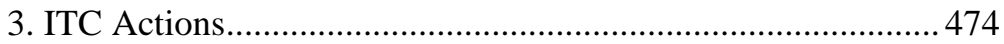

4. Post-Verdict Settlements.......................................................... 474

5. Patent Compulsory Licenses ........................................................ 476

C. Bargaining Around Compulsory Licenses in Copyright Cases ...... 476

1. Settling Liability Rule Cases ....................................................... 477

2. Collective Rights Organizations and Rate Rulemaking ............ 477

3. Negotiating Around Fixed Prices............................................... 478

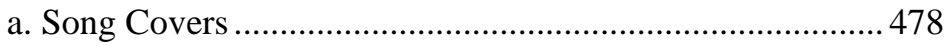

b. Cable Retransmission ........................................................... 479

c. Zero-Price Liability Rules..................................................... 480

III. Implications for the Debate over Property Rules and Liability Rules ...... 483

\section{INTRODUCTION}

In his influential article Contracting into Liability Rules: Intellectual Property Rights and Collective Rights Organizations, Robert Merges made the case that intellectual property (IP) owners vested with property entitlements can and do contract away their right to an injunction when it is efficient for them to do so. ${ }^{1}$ Merges's article was a huge step forward in the sophistication of entitlement theory, which had previously focused on the efficiency of the initial allocation of entitlements. ${ }^{2}$ Merges's key insight was that repeat players can contract around inefficient property rules and into more efficient transactions by forming collective rights organizations, a process that "significantly reduces state involvement in the creation of efficient entitlements." ${ }^{3}$ Merges demonstrated a seemingly critical asymmetry between property rules and liability rules, thus cementing for many the superiority of property rules over liability rules. Merges's evidence suggested that if a judge or a legislature gets the damages calculation wrong, we are stuck with an inefficient liability rule, but that we aren't similarly stuck with an inefficiently-allocated property rule. ${ }^{4}$

The evidence Merges brought to bear in his pathbreaking article is extremely important. By providing empirical evidence from various patent pools and copyright collectives, Merges enriched our consideration of how entitlement schemes will play out in the real world. But the picture Merges painted was incomplete. True, parties can contract around inefficient property rules in IP cases. But, as I show in this Essay, they can-and do-contract around inefficient liability rules as well. This is an important adjunct to Merges's key insight. My evidence does not prove the superiority of liability

1. Robert P. Merges, Contracting into Liability Rules: Intellectual Property Rights and Collective Rights Organizations, 84 CALIF. L. REV. 1293 (1996) [hereinafter Merges, Contracting].

2. See, e.g., Guido Calabresi \& A. Douglas Melamed, Property Rules, Liability Rules, and Inalienability: One View of the Cathedral, 85 HARV. L. REV. 1089, 1123-24, 1128 (1972).

3. Id. at 1297.

4. Id. 
rules over property rules, ${ }^{5}$ but it does undermine a major premise that has been used to support the claim that IP rights must be protected by property rules.

In Part I, I discuss the background for the debate over property rules and liability rules in IP, and how Merges's article made the case for the superiority of property rules by showing that parties will contract around property rules to avoid the problems of holdup. In Part II, I show that parties contract around liability rules at least as often as they bargain around property rules. I discuss bargaining around a variety of liability rules in IP, including settlements, suits against the government, and International Trade Commission (ITC) actions in patent cases, and compulsory licenses and "zero-price" liability rules in copyright cases. Finally, in Part III, I consider how parties' willingness to contract around liability rules affects the overall debate in IP regarding the desirability of property rules versus liability rules.

I.

PROPERTY RulEs, LIABILITY RULES, AND CONTRACTING

Courts and scholars have long debated the relative merits of general property rules and liability rules. ${ }^{6}$ The basic economic literature suggests that injunction-based property rules are easier to administer, at least if the parties can contract with each other, while liability rules can allocate rights among strangers, at least if we think judges can be relied on to calculate damages

5. For a more detailed discussion of that question, see Mark A. Lemley \& Philip J. Weiser, Should Property or Liability Rules Govern Information?, 85 TEX. L. REV. 783 (2007); Richard A. Epstein \& F. Scott Kieff, Questioning the Frequency and Wisdom of Compulsory Licensing for Pharmaceutical Patents, 78 U. CHI. L. REV. 71 (2011); Jerome H. Reichman, Compulsory Licensing of Patented Pharmaceutical Inventions: Evaluating the Options, 37 J.L. MED. \& ETHICS 247 (2009).

6. The body of literature on this topic is extensive. See, e.g., Ian Ayres \& Eric Talley, Solomonic Bargaining: Dividing a Legal Entitlement to Facilitate Coasean Trade, 104 YALE L.J. 1027, 1101-02 (1995); Reza Dibadj, Regulatory Givings and the Anticommons, 64 OHIO ST. L.J. 1041, 1113-15 (2003); Louis Kaplow \& Steven Shavell, Property Rules Versus Liability Rules: An Economic Analysis, 109 HARV. L. REV. 713, 719 (1996); James E. Krier \& Stewart J. Schwab, Essay, Property Rules and Liability Rules: The Cathedral in Another Light, 70 N.Y.U. L. REV. 440 (1995); A. Mitchell Polinsky, Resolving Nuisance Disputes: The Simple Economics of Injunctive and Damage Remedies, 32 StAN. L. REV. 1035 (1980); Lucian Arye Bebchuk, Ex Ante Investments and Ex Post Externalities (Harvard Law Sch. Law \& Econ. Research Paper Series, Paper No. 397, 2002), available at http://ssrn.com/abstract=297091.

For a somewhat related debate on bright-line rules versus case-specific standards, see, for example, Frederick Schauer, Playing by the Rules: A Philosophical Examination of Rule-BASED DECISION-MAKING IN LAW AND IN LIFE (1991); Louis Kaplow, Rules Versus Standards: An Economic Analysis, 42 DUKE L.J. 557 (1992); Duncan Kennedy, Form and Substance in Private Law Adjudication, 89 HARV. L. REV. 1685 (1976); Russell B. Korobkin, Behavioral Analysis and Legal Form: Rules vs. Standards Revisited, 79 OR. L. REV. 23 (2000); Eric A. Posner, Standards, Rules, and Social Norms, 21 HARV. J.L. \& PUB. POL'Y 101 (1997); Pierre Schlag, Rules and Standards, 33 UCLA L. REV. 379 (1985); Cass R. Sunstein, Problems with Rules, 83 CALIF. L. REV. 953 (1995). On the merits of rules and standards in patent law, see ROBERT P. MERGES \& JOHN FITZGERALD DUfFy, PATENT LAW AND POLICY 805-06 (3d ed. 2002); John R. Thomas, Formalism at the Federal Circuit, 52 AM. U. L. REV. 771 (2003); R. Polk Wagner, Reconsidering Estoppel: Patent Administration and the Failure of Festo, 151 U. PA. L. REV. 159, 234-37 (2002). 
accurately. $^{7}$ The essential insight is that court determinations of damages carry a risk of error: the court might value the property at more or less than it is really worth. A property rule gives ownership of the property to one party, allowing that party to sell the right to another if it is efficient to do so. Accordingly, the literature suggests that in a world with no transactions costs, it wouldn't matter to whom we gave ownership of the property; the parties would contract to pass it on to the highest-value user. ${ }^{8}$ Introducing transactions costs complicates the inquiry, because assigning a property right to an inefficient user is a problem if we can't expect the parties to agree to correct the improper assignment. Thus, where the cost of transacting is high, either because there are many parties who must agree or because it is difficult for the parties to find and deal with each other ex ante, we may be better served by taking our chances with a court allocation of damages than having the law lock in an inefficient ownership regime. ${ }^{9}$

\section{A. Property Rules and Liability Rules in IP Cases}

In IP cases, where debates over the wisdom of compulsory licensing are common, ${ }^{10}$ academic discussions about property rules and liability rules have tended to focus on the unique nature of the IP right as a reason to favor property rules over liability rules. ${ }^{11}$ An IP right is, by definition, novel and

7. Calabresi \& Melamed, supra note 2, at 1123-24, 1128. Their article too has spawned an extensive literature. See, e.g., Ayres \& Talley, supra note 6; Jason Scott Johnston, Bargaining Under Rules Versus Standards, 11 J.L. ECON. \& ORG. 256 (1995); Krier \& Schwab, supra note 6.

8. R.H. Coase, The Problem of Social Cost, 3 J.L. \& ECON. 1 (1960).

9. For a more detailed discussion, see RICHARD POSNER, ECONOMIC ANALYSIS OF LAW 3172 (4th ed. 1992).

10. For proposals to implement compulsory licenses for digital copyright, see, for example, WiLliam W. FiSHER III, PROMISES TO KEEP (2006); Glynn S. Lunney, Jr., The Death of Copyright: Digital Technology, Private Copying, and the Digital Millennium Copyright Act, 87 VA. L. REV. 813, 916 (2001); Neil Weinstock Netanel, Impose a Noncommercial Use Levy to Allow Free Peer-to-Peer File Sharing, 17 HARV. J.L. \& TECH. 1 (2003). For a proposal to implement compulsory licenses for music sampling, see Olufunmilayo B. Arewa, From J.C. Bach to Hip Hop: Musical Borrowing, Copyright and Cultural Context, 84 N.C. L. REV. 547, 635-41 (2006). For an argument for compulsory licensing of pharmaceutical patents, see, for example, Simone A. Rose, On Purple Pills, Stem Cells, and Other Market Failures: A Case for a Limited Compulsory Licensing Scheme for Patent Property, 48 How. L.J. 579, 618-24 (2005). For a more skeptical view, see Michael Botein \& Edward Samuels, Compulsory Licenses in Peer-to-Peer File Sharing: A Workable Solution?, 30 S. ILL. U. L.J. 69 (2005). And for an argument in the other direction-to abolish existing compulsory licenses - see Paul Goldstein, Copyright on a Clean Slate, 48 Hous. L. REV. (forthcoming Winter 2011); Section 115 of the Copyright Act: In Need of an Update?: Hearing Before the Subcomm. on Courts, the Internet and Intellectual Property of the H. Comm. on the Judiciary, 108th Cong. 5 (2004) [hereinafter Section 115 Hearings] (oral statement of Marybeth Peters, Register of Copyrights) (describing the cover license as unworkable and recommending it be deleted).

11. See, e.g., RoBert P. MERges ET AL., InTEllectual Property in the NeW TECHNOLOGICAL AGE 377-79 (5th ed. 2010); Epstein \& Kieff, supra note 5; David McGowan, The Trespass Trouble and the Metaphor Muddle, 1 J.L. ECON. \& POL'Y 109 (2005); Robert P. Merges, To Waive and Waive Not: Property and Flexibility in the Digital Era, 34 COLUM. J.L. \& ARTS 113 (2011); R. Polk Wagner, Essay, Information Wants to Be Free: Intellectual Property and the 
different from other IP rights. As a result, there is no thick market to which courts can turn to value IP rights, so courts might be expected to get the damages calculation wrong with some frequency. ${ }^{12}$ Further, because IP rights are meant to give the owner some power over price, at least in some instances, the calculation of liability is complicated by the fact that, even if there were a competitive market, a competitive market return is not what IP rights are supposed to give. Courts and legislatures may therefore be called upon to award damages not on the basis of a lost transaction fee, but to reconstruct the market that might have existed but for the infringement. ${ }^{13}$ The first inquiry is hard enough and, as reasonable royalties in patent cases have shown, courts arguably don't do it very well. ${ }^{14}$ The second might as well be economic necromancy. ${ }^{15}$

If courts are not expected to do well at setting damages in IP cases, the Calabresi-Melamed framework ${ }^{16}$ suggests IP rights ought to be protected by a property rule. ${ }^{17}$ And so it has been. Even before we called IP intellectual

Mythologies of Control, 103 ColuM. L. REV. 995 (2003); cf. Mark Schankerman \& Suzanne Scotchmer, Damages and Injunctions in Protecting Intellectual Property, 32 RAND J. ECON. 199 (2001) (finding the issue substantially more complicated).

12. For discussion of the problems with a thick market in IP, see Mark A. Lemley \& Nathan Myhrvold, How to Make a Patent Market, 36 HofsTRA L. REV. 257 (2008); Jerome H. Reichman \& Tracy Lewis, Using Liability Rules to Stimulate Local Innovation in Developing Countries: Application to Traditional Knowledge, in INTERNATIONAL PUBLIC GOODS AND TRANSFER OF TEChNology Under a Globalized InTELlectual Property Regime 337 (Keith E. Maskus \& Jerome H. Reichman eds., 2005) (making the point that sellers overvalue their inventive contributions and buyers undervalue them); David J. Teece, The Market for Know-How and the Efficient International Transfer of Technology, 458 ANNALS AM. ACAD. POL. \& SOC. SCI. 81, 88 (1981) ("[N]either buyer nor seller of technology seems to have a clear idea of the value of the commodity in which they are trading ....”" (quoting Peter Killing, Technology Acquisition: License Agreement or Joint Venture, COLUM. J. WORLD BUS., Fall 1980, at 38, 44)).

13. See Epstein \& Kieff, supra note 5.

14. See, e.g., Daralyn J. Durie \& Mark A. Lemley, A Structured Approach to Calculating Reasonable Royalties, 14 LEWIS \& CLARK L. REV. 627 (2010); Mark A. Lemley \& Carl Shapiro, Patent Holdup and Royalty Stacking, 85 TEX. L. REV. 1991 (2007); Brian J. Love, The Misuse of Reasonable Royalty Damages as a Patent Infringement Deterrent, 74 Mo. L. REV. 909 (2009).

15. See, e.g., Mark A. Lemley, Distinguishing Lost Profits From Reasonable Royalties, 51 WM. \& MARY L. REV. 655 (2009); Brian J. Love, Note, Patentee Overcompensation and the Entire Market Value Rule, 60 STAN. L. REV. 263 (2007).

16. For a succinct summary of Calabresi and Melamed's framework, see Merges, Contracting, supra note 1, at 1302-03. Their framework distinguishes between "property rules," which allow owners of an entitlement to enlist the aid of a court to forbid access to a property immediately (and thus determine the rate they will charge the party seeking access), and "liability rules," which require owners of the entitlement to bring suit for damages after the party has accessed the property without permission (and thus require the "collective valuation" of a judge or jury hearing the claim).

17. Jules L. Coleman \& Jody Kraus, Rethinking the Theory of Legal Rights, 95 YALE L.J. 1335, 1339 (1995); Richard A. Epstein, A Clear View of The Cathedral: The Dominance of Property Rules, 106 YALE L.J. 2091, 2092-96 (1997) [hereinafter Epstein, Clear View]; Richard A. Epstein, Steady the Course: Property Rights in Genetic Material, in PERSPECTIVES ON PROPERTIES OF THE HumAn Genome PROJECT 153 (F. Scott Kieff ed., 2003); Robert P. Merges, A Transactional View of Property Rights, 20 BERKELEY TECH. L.J. 1477 (2005); Henry E. Smith, Property and Property Rules, 79 N.Y.U. L. REV. 1719 (2004). 
"property," courts applied property-like remedies to IP cases as a matter of course. $^{18}$ The vast majority of patent cases in the nineteenth century were brought as suits in equity, not law, because the plaintiff was more interested in injunctive relief than in damages. ${ }^{19}$ Each of the major IP statutes provide for injunctive relief in accordance with the principles of equity. ${ }^{20}$ And until the Supreme Court held that the traditional four-factor test for issuing permanent injunctions applied in the patent context, ${ }^{21}$ an injunction was essentially a required remedy in Federal Circuit patent cases. ${ }^{22}$

The biggest risk of applying property rules in IP cases is holdup. An IP owner with a right to injunctive relief can demand the full value of the defendant's use as a condition of approving it. ${ }^{23}$ In the paradigm case of infringement by copying, we might not worry too much about holdup, viewing it as a Nash bargaining issue in which the parties can find a mutually-beneficial solution regardless of the starting entitlement. ${ }^{24}$ But, if we think the defendant is not merely a copyist but an improver, we might worry about the allocation of rights between the two, since an injunction could prevent society from benefitting from the improvement. And indeed we have patent doctrines, such as the blocking patents rule and the (rarely used) reverse doctrine of equivalents, to deal with just that situation. ${ }^{25}$ We might worry more if the patent covers only a small component of the defendant's product because, at least in the short term, an injunction is likely to shut down the entire product,

One important factor cutting in the other direction seems to have been neglected in the scholarship: that, in patent cases at least, the overwhelming majority of suits involve parties who were strangers to each other. See Christopher A. Cotropia \& Mark A. Lemley, Copying in Patent Law, 87 N.C. L. REV. 1421 (2009). The case for property rules is based on the idea that, as Merges and Duffy put it, “[p]rivate, pre-infringement transfers are probably better.” ROBERT PATRICK MERGES \& JOHN FITZGERALD DUfFy, PATENT LAW AND POLICY 1067 (3d ed. 2002). But if the litigating parties are strangers to each other, the liability regime of tort law looks far more plausible than one encouraging those strangers to find each other and contract in advance.

18. eBay Inc. v. MercExchange L.L.C., 547 U.S. 388, 394 (2006) (Roberts, C.J., concurring) (noting the history of granting injunctions in IP cases).

19. See Stephen Lubar, The Transformation of Antebellum Patent Law, 32 TECH. \& CULTURE 932, 958 (1991) ("The growth of equity . . . allowed judges to take patent law into their own hands. A hearing before a judge, followed by an injunction, became the general rule in patent cases.”).

20. 15 U.S.C. $\S 1116($ a) (2006) (trademarks: “[C]ourts . . . shall have power to grant injunctions, according to the principles of equity and upon such terms as the court may deem reasonable ... .”); 17 U.S.C. § 502(a) (copyrights: a court may "grant temporary and final injunctions on such terms as it may deem reasonable”); 35 U.S.C. $\S 283$ (patents: "[C]ourts . . . may grant injunctions in accordance with the principles of equity.").

21. eBay, 547 U.S. at 391-92. For further discussion of eBay, see infra Subsection II.B.1.

22. Id. at 391-94.

23. See, e.g., Lemley \& Shapiro, supra note 14.

24. John F. Nash, Jr., The Bargaining Problem, 18 ECONOMETRICA 155 (1950).

25. For discussion of these doctrines, see, for example, Mark A. Lemley, The Economics of Improvement in Intellectual Property Law, 75 TEX. L. REV. 989, 1000-13 (1997); Robert P. Merges, Intellectual Property Rights and Bargaining Breakdown: The Case of Blocking Patents, 62 TENN. L. REV. 75 (1994); Robert P. Merges \& Richard R. Nelson, On the Complex Economics of Patent Scope, 90 COLUM. L. REV. 839, 860-68 (1990). 
causing harm potentially far greater than the value of the patent on a single component. Patentees in these cases have recognized and exploited this potential to demand settlements far in excess of the value of their technological contribution. $^{26}$ And we really might worry if, to make a product, a manufacturer might have to enter into hundreds or even thousands of different transactions. Scholars have talked about the multiple holdup problems that result under the names "anticommons" or "patent thickets." 27 Whatever the name, the problem of multiple holdups might seem the Achilles heel for property rules as applied to the real world of modern IP cases. If the risk of multiple injunctions makes it infeasible to build a complex, multicomponent product such as a car or a semiconductor chip, that would provide a strong counterweight to the property rule argument. ${ }^{28}$

\section{B. Contracting into Liability Rules}

Enter Merges's seminal article. In Contracting into Liability Rules, Merges argues that parties can avoid the holdup problem by contracting around property rules, and that they do so even in circumstances where the number and diversity of rights at issue might seem to make holdup problems insurmountable. $^{29}$ Merges's examination of collective rights organizations "stand[s] conventional entitlements theory on its head." $30 \mathrm{He}$ points to a number of examples in which groups of IP owners come together to agree to forego their right to injunctive relief in the interest of making patent markets work. Patentees enter into patent pools, agreeing collectively to license their patents and split the profits. ${ }^{31}$ Technology companies join standard-setting organizations that impose limits on IP rights that cover the standard. ${ }^{32}$ Copyright owners agree en masse to join collective-rights organizations like

26. Lemley \& Shapiro, supra note 14.

27. See, e.g., Michael A. Heller \& Rebecca S. Eisenberg, Can Patents Deter Innovation? The Anticommons in Biomedical Research, 280 SCIENCE 698, 698 (1998); Carl Shapiro, Navigating the Patent Thicket: Cross Licenses, Patent Pools, and Standard-Setting, in 1 INNOVATION POLICY AND THE ECONOMY 119 (Adam Jaffe et al. eds., 2000). While both “anticommons” and "patent thicket” are terms used to describe situations in which a party must license multiple patent rights, I have elsewhere disambiguated the two. An anticommons occurs when a downstream purchaser must obtain rights to many different discrete components. A patent thicket occurs when patents covering nominally different ideas overlap, so that even practicing one invention can require multiple licenses. See DAN L. Burk \& MARK A. LEMLEy, The PATENT CRISIS AND HOW THE COURTS CAN SOLVE IT 75-78 (2009).

28. For a limited argument along these lines, see Christopher M. Newman, Patent Infringement as Nuisance, 59 CATH. U. L. REV. 61 (2009). To be sure, damage awards can also create a holdup problem because of “royalty stacking.” See Lemley \& Shapiro, supra note 14.

29. Merges, Contracting, supra note 1, at 1296-97.

30. Id. at 1296.

31. Id. at 1340-58 (citing examples).

32. Id. at 1327-40; see also Mark A. Lemley, Intellectual Property Rights and StandardSetting Organizations, 90 CALIF. L. REV. 1889 (2002). 
ASCAP $^{33}$ and $\mathrm{BMI}^{34}$ avoiding an enormous transactions costs problem in connecting millions of copyright owners to hundreds of broadcasters and tens of thousands of stores, bars, and restaurants. ${ }^{35}$

Merges's evidence that IP owners can agree together to avoid holdup problems, even in extraordinary numbers, significantly bolstered the case for property rules over liability rules. If we don't have to worry much about holdup, because IP owners will efficiently contract away their right to exclude, property rules start to seem systematically better than liability rules. After all, in a market economy we are more likely to trust the parties to collectively set the right price than we are to trust courts or legislatures to do so. ${ }^{36}$ As a result, Merges's article seemed for many to cement the case for property rules over liability rules in IP cases. ${ }^{37}$ Indeed, some went so far as to claim that, given the ability of parties to bargain around property rules, it was liability rules that created the true anticommons problem by miring the parties in rate regulation proceedings they could not easily escape. ${ }^{38}$ Merges himself concludes that the government should "stay away from compulsory licensing," leaving it to private organizations to bargain around property rules if necessary. ${ }^{39}$ And elsewhere he has argued that property rights should be expanded into areas of creativity they don't currently reach, such as Wikipedia-secure in the belief that contributors will bargain around that entitlement. ${ }^{40}$

II.

\section{CONTRACTING AROUND LIABILITY RULES}

Merges's article provides valuable evidence in this ongoing debate. But the conclusion that property rules are superior to liability rules relies not just on this evidence, but on an assumed asymmetry between property rules and

33. American Society of Composers, Authors and Publishers.

34. Broadcast Music, Inc.

35. Merges, Contracting, supra note 1, at 1329-35.

36. See id. at 1300, 1367 (arguing that parties are better positioned than courts to value IP rights).

37. See, e.g., Christopher S. Yoo, Free Speech and the Myth of the Internet as an Unintermediated Experience, 78 GEO. WASH. L. REV. 697, 710 (2010) (citing Merges as evidence for the ability of private organizations to solve multiparty bargaining problems); F. Scott Kieff, Patents for Environmentalists, 9 WASH. U. J.L. \& POL'Y 307, 314-15 (2002).

38. See F. Scott Kieff, IP Transactions: On the Theory and Practice of Commercializing Innovation, 42 Hous. L. REV. 727, 742 (2005) (asserting that liability rules create a "pernicious permit thicket or License Raj"); Smith, supra note 17, at 1731 (arguing that liability rules increase information costs relative to property rules because actors must determine the cost of compliance); $c f$. Richard A. Epstein, The Permit Power Meets the Constitution, 81 IowA L. REV. 407 (1995) (discussing the problem of permit thickets).

39. Merges, Contracting, supra note 1, at 1300. For a continued defense of that idea more than a decade later, albeit one with moral rather than economic undertones, see Robert P. Merges, Essay, The Concept of Property in the Digital Age, 45 Hous. L. REV. 1239, 1269-71 (2008).

40. Robert P. Merges, Locke for the Masses: Property Rights and the Products of Collective Creativity, 36 HOFSTRA L. REV. 1179 (2008). 
liability rules: that while parties might bargain around property rules, they won't similarly bargain around liability rules. In this Part, however, I discuss evidence from a variety of sources suggesting that parties can and do bargain around liability as well as property rules in IP.

\section{A. Liability Rules in IP}

As noted above, IP rights are generally protected by property rules. However, injunctive relief is not always available, and the circumstances in which IP law uses liability rules provide opportunities to test Merges's suggested asymmetry. For example, patentees who sue the U.S. government are entitled under 28 U.S.C. § 1498 to sue in the Court of Claims for "reasonable and entire compensation" for government infringement of their patents, but are not entitled to an injunction. ${ }^{41}$ A few patent statutory provisions permit the government to require licensing of publicly-funded or environmental inventions in the public interest. ${ }^{42}$ After $e$ Bay, patent plaintiffs who do not practice their invention are almost never entitled to injunctive relief. ${ }^{43}$ Copyright law creates a labyrinthine series of compulsory licenses, some of which rely on courts or administrative law judges (ALJs) to set rates while others set the rate in statutes or rules. ${ }^{44}$ And there are a number of limits on the scope of IP rights that serve as a sort of zero-price liability rule.

41. 28 U.S.C. $\S 1498$ (2006).

42. 7 U.S.C. $\S 2404$ (Plant Variety Protection Act provision allowing the Secretary of Agriculture to make patented plants available to assure "adequate supply of fiber, food or feed"); 35 U.S.C. § 203 (creating government "march-in rights" to compel licensing of publicly-funded inventions); 42 U.S.C. § 7608 (providing for compulsory licensing of inventions necessary to comply with air pollution standards). For discussions of these provisions, see Daniel R. Cahoy, Breaking Patents, 32 Mich. J. INT’L L. 461 (2011); Lorelei Ritchie De Larena, What Copyright Teaches Patent Law About "Fair Use" and Why Universities Are Ignoring the Lesson, 84 OR. L. REV. 779, 814-16 (2005).

43. See Mark A. Lemley, The Ongoing Confusion Over Ongoing Royalties, 76 Mo. L. REv. 695 (2011). For data on injunctive relief after eBay, see J. Scott Larson, The Unsettled Aftereffects of eBay and Survey of Its Continued US Litigation Impact, INTELL. PROP. \& TECH. L.J., Mar. 2010, at 5. The complete statistics are available on the University of Houston Patstats website. H. Jarrah ed., Post eBay Perm. Injunctions by District Courts, PATSTATS (Aug. 11 2011), http://www.patstats.org/ Injunction_rulings_post-eBay_to_08-11-2011 xls [hereinafter PATSTATS].

44. See, e.g., 17 U.S.C. $\S \S 111-112,114-116,119$.

There are other forms of compulsory licensing as well. Antitrust agencies often impose licensing requirements as part of consent decrees settling antitrust charges or allowing mergers. See, e.g., F.M. SCHERER, THE ECONOMIC EFFECTS OF COMPULSORY PATENT LICENSING (1977). I do not include these individualized outcomes because they don't involve a liability rule, but rather a party being forced to forego a property rule. For discussion of these sorts of licenses, see, for example, JEROME H. REICHMAN \& CATHERINE HASENZAHL, ICTSD-UNCTAD PROJECT ON IPRS \& SUST. DEV., NONVOLUNTARY LICENSING OF PATENTED INVENTIONS 21-22 (2003); SCHERER, supra. For an empirical study showing that even these consent decrees usually didn't require resort to rate-setting by courts, see Daniel A. Crane, Bargaining in the Shadow of Rate-Setting Courts, 76 ANTITRUST L.J. 307 (2009) [hereinafter Crane, Bargaining]; Daniel A. Crane, Intellectual Liability, 88 TEX. L. REv. 253, 294 (2009) [hereinafter Crane, Intellectual Liability]. 
Evidence from each of these IP liability rules shows that parties contract around liability as well as property rules. Most of those examples involve contracting at a time of legal uncertainty, such as the settlement of a liability rule dispute for money. But, that is true of Merges's examples as well. As Carl Shapiro has noted, a patent is not a right to exclude, but a right to try to exclude; ${ }^{45}$ patent owners who join a patent pool and agree to license their patents are not giving up a certain right to injunctive relief, but only a chance of winning a patent case. And when patentees do sue to enforce their patents, they lose three times out of four. ${ }^{46}$ Similarly, patent and copyright owners who contract to settle a liability rule case are resolving uncertainty as to liability as well as damages. Curiously, though, even when a liability rule entitlement is clear, parties will sometimes contract around it, as evidence from the copyright compulsory licenses makes clear.

\section{B. Liability Rules, Property Rules, and Settlement in Patent Cases}

I begin with evidence from patent cases. This evidence makes a useful comparison because, with the exception of remedies, the patent laws facing plaintiffs entitled to injunctive relief and those entitled only to damages are otherwise identical.

\section{Settlements After eBay}

Patent plaintiffs before 2006 were entitled to injunctive relief as a matter of course if they won their cases. ${ }^{47}$ But eBay changed that. Beginning in 2006, and notwithstanding the Supreme Court's requirement that injunctions be considered on a case-by-case basis, application of the four eBay factors ${ }^{48}$ almost always results in nonpracticing entities (NPEs) ${ }^{49}$ being denied injunctive relief. ${ }^{50}$ Some have argued that the inability to seek an injunction

45. Mark A. Lemley \& Carl Shapiro, Probabilistic Patents, J. ECON. PERSP., Spring 2005, at 75, 75 (“[E]conomists have increasingly recognized that a patent does not confer upon its owner the right to exclude but rather a right to try to exclude by asserting the patent in court.”); Carl Shapiro, Antitrust Limits to Patent Settlements, 34 RAND J. ECON. 391, 395 (2003) (“[A] patent is best viewed as a probabilistic property right.”).

46. Paul M. Janicke \& LiLan Ren, Who Wins Patent Infringement Cases?, 34 AIPLA Q.J. 1, 8 (2006).

47. eBay Inc. v. MercExchange, L.L.C., 547 U.S. 388, 391 (2006) (discussing the Federal Circuit rule).

48. Id. ("A plaintiff must demonstrate: (1) that it has suffered an irreparable injury; (2) that remedies available at law, such as monetary damages, are inadequate to compensate for that injury; (3) that, considering the balance of hardships between the plaintiff and defendant, a remedy in equity is warranted; and (4) that the public interest would not be disserved by a permanent injunction.”).

49. Non-practicing entities (a k.a., "patent trolls") are those who own a patent and sue to enforce it, but don't actually practice the patent themselves. See John R. Allison et al., Extreme Value or Trolls on Top? Evidence From the Most-Litigated Patents, 158 U. PA. L. REV. 1 (2009).

50. See PATSTATS, supra note 43 (collecting all cases granting and denying injunctive relief). I compared that list to a collection of entity status data I am developing, and determined that while about 75 percent of injunction requests are granted post-eBay, virtually all of those grants are to practicing 
may make patentees less likely to settle their cases. ${ }^{51}$ Nonetheless, NPEs are no less likely to settle their cases than are other patentees; indeed, NPE cases settle at a slightly higher rate (89.5 percent versus 86.5 percent), though the difference is not statistically significant. ${ }^{52}$

\section{Suits Against the Government}

A second set of patent cases helps cement the point. Patentees who sue the government are limited to "reasonable and entire compensation" by the statute. $^{53}$ The Federal Circuit has rejected the theory that this statute works a taking of private property, ${ }^{54}$ but it and its predecessor courts have acknowledged that the United States is effectively "a compulsory, nonexclusive licensee" under the statute. ${ }^{55}$ The Court of Claims, which hears all such patent cases, rules for the patentee about one time in three, and awards damages in perhaps four cases a year. ${ }^{56}$ But while Court of Claims-specific statistics are not available, it appears that far more cases against the government settle, either after the suit is filed or before ever reaching court. ${ }^{57}$ While more data is required to draw a definitive conclusion, the fact that there is no threat of injunction does not appear to incline the government to take their chances in court any more than defendants anywhere.

entities. NPEs are essentially never granted injunctions; some practicing entities are also denied injunctive relief.

51. See, e.g., Lily Lim \& Sarah E. Craven, Injunctions Enjoined; Remedies Restructured, 25 SANTA CLARA COMPUTER \& HIGH TECH. L.J. 787, 818 (2009).

52. John R. Allison et al., Patent Quality and Settlement Among Repeat Patent Litigants, 99 GEO. L.J. 677 (2011). Those cases span the last decade, so they do not specifically distinguish between pre-2006 and post-2006 cases. Breaking out that data to include only post-2007 decisions shows a small but statistically significant change in the percentage of cases that involve settlements, from an annual average of 66 percent before $e B a y$ to 63 percent in the years since $e B a y$. (These numbers are not directly comparable to the higher percentages in the text because the text numbers exclude pending cases, procedural dismissals, and transfer rulings). So, there is some evidence that the move to a partial liability rule in patent cases coincided with a slight decline in the number of settlements, though the data do not prove causation.

53. 28 U.S.C. $\S 1498$ (2006).

54. Zoltek Corp. v. United States, 442 F.3d 1345, 1347 (Fed. Cir. 2006).

55. Motorola, Inc. v. United States, 729 F.2d 765, 768 (Fed. Cir. 1984); Irving Air Chute Co. v. United States, 93 F. Supp. 633, 635 (Ct. Cl. 1950) (section 1498 is "in effect, an eminent domain statute").

56. J.H. REICHMAN, COMPULSORY LiCENSING OF PATENTED INVENTIONS: COMPARING UNITED STATES LAW AND PRACTICE WITH OPTIONS UNDER THE TRIPS AGREEMENT 6 (2006), available at http://www.aals.org/documents/2006intprop/JeromeReichmanOutline pdf.

57. Id. at 7 ("What has been omitted from this picture, but which palpably influences any overall assessment of section 1498, is the frequency with which the government and the affected patentees negotiated settlements without resort to litigation.”); REICHMAN \& HASENZAHL, supra note 44. 


\section{ITC Actions}

Comparison to patent cases brought before the International Trade Commission (ITC) ${ }^{58}$ is also instructive. The ITC is in some sense the inverse of the Court of Claims; patentees can only obtain injunctive relief, not damages. If IP owners were more likely to contract around property rules than liability rules, we should expect settlements in the ITC to be higher than the 89.5 percent NPE settlements, or at least higher than the average 75-85 percent general settlement rate. ${ }^{59}$ In fact, however, empirical evidence shows the opposite: ITC cases explicitly settle only 45 percent of the time. ${ }^{60}$ Even if we count complainants' voluntary withdrawals of a complaint as settlements, which they may or may not be, the settlement rate rises only to 56 percent. $^{61}$ True, there are differences between the ITC and the district courts, notably the speed with which ITC cases are resolved. But speed can't be the explanation; even the fastest district courts, which get to trial as fast as or faster than the ITC, settle nearly as many cases as the national average. ${ }^{62}$ If anything, the data suggest that parties are more likely to settle in the shadow of liability rules than of property rules. They certainly don't suggest the reverse.

\section{Post-Verdict Settlements}

It is true that the evidence I have discussed so far concerns the settlement of disputes that involve uncertainty as to the underlying merits. Perhaps the

58. The ITC is an alternative to federal district courts as a venue to enforce a United States patent, issuing relief for unfair methods of competition and unfair acts of importing goods or selling imported goods under 19 U.S.C. § 1337. See generally Sheldon Meyer \& Mark Miller, Patent Litigation Before the International Trade Commission and Its Effectiveness (1988-1992), 350 PRACTISING L. INST. PATS. LiTIG. 495, 501 (1992), available at Westlaw, 350 PLI/Pat 495.

59. The settlement rate in patent cases across all districts is 74.7 percent if we include procedural dispositions as non-settlements, and 83.4 percent if we exclude them. Data calculated from www.lexmachina.com. https://lexmachina.com/members/cases/outcomes (password required).

60. Robert W. Hahn \& Hal Singer, Assessing Bias in Patent Infringement Cases: A Review of International Trade Commission Decisions, 21 HARV. J.L. \& TECH. 457, 475 tbl.1. Curiously, Hahn and Singer argue that settlements should all be treated as patentee wins, a theory that makes no sense given that those settlements are confidential and may well include cases in which the patentees drop the case for no compensation at all. But that error doesn't affect the data I report here. For other empirical work on the ITC with consistent results, see Colleen V. Chien, Patently Protectionist? An Empirical Analysis of Patent Cases at the International Trade Commission, 50 WM. \& MARY L. REV. 63, 64 (2008) (finding that 44 percent of ITC patent cases go to judgment, four times as many as in ordinary patent litigation).

61. Hahn \& Singer, supra note 60, at 20; Chien, supra note 60.

62. The three fastest districts are the Eastern District of Virginia, the Middle District of Florida, and the Western District of Wisconsin. Mark A. Lemley, Where to File Your Patent Case, 38 AIPLA Q.J. 401, 416 (2010). The Eastern District of Virginia settles 85.5 percent of its patent cases (313 of 366), more than the national average of 83.4 percent. The Middle District of Florida settles 84.7 percent (361 of 426), also more than the national average. Only the Western District of Wisconsin, which settles 75.4 percent of its cases (196 of 260), is below the national judicial average. But even the Western District of Wisconsin settles far more cases than does the ITC. Data from www.lexmachina.com/members/cases/outcomes. 
uncertainty of outcome is enough to cause risk-averse parties to settle rather than chance a bad outcome. ${ }^{63}$ But, as noted above, that is true of the data on contracting around property rules as well.

Nonetheless, there is also evidence that parties settle cases even after the imposition of a liability rule. While many cases settle before trial, parties also settle cases after trial. For our purposes, the relevant question is how many cases settle after the plaintiff wins a case but the court refuses to award an injunction. There are relatively few such cases; when that does happen, the parties settle 31.25 percent of the time after the trial rather than going to appeal. ${ }^{64}$ While that seems low, and certainly lower than the overall percentage of patent cases settled, it is worth keeping in mind that at this point the parties have already spent the bulk of the money on the case, and the fact that they didn't settle before trial may indicate animosity or some other issue between the parties that discourages settlement. And indeed, only 16.67 percent of cases in which an injunction was granted settled after the grant of injunction rather than going to appeal. ${ }^{65}$ Far from discouraging bargaining, if anything, the denial of an injunction in a patent case appears more conducive to settlement than its grant. The mechanism may be what Rochelle Dreyfuss calls a "credible threat": "Knowing that arrangements will be imposed if they do not act voluntarily, patentees are pushed to the bargaining table."66

63. Notably, the dominant economic paradigm for predicting what cases are selected for trial assumes the opposite. Priest and Klein hypothesized that win rates in litigated cases should approach 50 percent because it is the cases with the most uncertainty that parties would not settle. George L. Priest \& Benjamin Klein, The Selection of Disputes for Litigation, 13 J. LEGAL STUD. 1, 24 (1984). A theory that uncertainty drives settlement assumes precisely the opposite.

The Priest-Klein hypothesis has been challenged as a matter of theory. See, e.g., Steven Shavell, Any Frequency of Plaintiff Victory at Trial Is Possible, 25 J. LEGAL STUD. 493 (1996); Carol Rose, Crystals and Mud in Property Law, 40 StAN. L. REV. 577, 577-78 (1988); Dan L. Burk, Muddy Rules for Cyberspace, 21 CARDOZO L. REV. 121 (1999). Empirical evidence from IP cases is inconsistent with the prediction that win rates gravitate towards 50 percent. See Allison et al., supra note 52, at 681 (repeat-litigated cases lose 90 percent of the time); Janicke \& Ren, supra note 46, at 8 tbl.1 (patentee win rate is only 24.4 percent overall); John R. Allison \& Mark A. Lemley, Empirical Evidence on the Validity of Litigated Patents, 26 AIPLA Q.J. 185, 206 n.53 (1998) (average patentee validity win rate was 35 percent before the creation of the Federal Circuit, and rose to 54.6 percent thereafter); Mark A. Lemley \& Colleen V. Chien, Are the United States Patent Priority Rules Really Necessary?, 54 HASTINGS L.J. 1299, 1310-12 (2003) (appellate win rates vary widely from 50 percent); Kimberly A. Moore, Judges, Juries, and Patent Cases-An Empirical Peek Inside the Black Box, 99 MiCH. L. REV. 365, 377-78 (2000).

64. Cases collected from PATSTATS, supra note 43. I cleaned the case data and then sampled outcomes using the docket entries available on www.lexmachina.org.

65. See supra note 52 for methodology.

66. Rochelle Cooper Dreyfuss, Varying the Course in Patenting Genetic Material: A CounterProposal to Richard Epstein's Steady Course, in PERSPECTIVES ON PROPERTIES OF THE HUMAN GENOME PROJECT, supra note 17, at 195, 202; Gianna Julian-Arnold, International Compulsory Licensing: The Rationales and the Reality, 33 IDEA 349 (1993). 


\section{Patent Compulsory Licenses}

Finally, the government has the power to compel licensing of certain patents on reasonable and nondiscriminatory terms. These various powers have apparently never been used. ${ }^{67}$ But they still have an effect. During the anthrax attacks on Washington, D.C., in the fall of 2001, there was great concern about the price and availability of Cipro, the only drug known to be effective against anthrax. $^{68}$ The government used the threat of invoking its march-in rights to force Bayer to the bargaining table and get it to lower the price of Cipro. ${ }^{69}$ Patent compulsory license rights have never been invoked in court, but the threat of invoking them has prompted the parties to bargain in their shadow.

In sum, evidence indicates that parties to patent cases bargain around liability rules at least as often as, if not more than, they contract around property rules. Nonpracticing entities negotiate even though an eventual injunction is unlikely, and patentees settle against the government in cases where an injunction is impossible. Comparison with ITC cases suggests that parties actually settle more often in the face of liability rulings than they do in the face of injunctions. Similarly, parties seem to settle more frequently after a verdict imposing a liability rule than after a verdict imposing an injunction. Finally, anecdotal evidence indicates that parties bargain in the shadow of government's power to compel licensing of certain patents.

\section{Bargaining Around Compulsory Licenses in Copyright Cases}

Copyright law provides an additional source of evidence that parties contract around liability rules as well as property rules. Unlike patent law, copyright law contains a number of compulsory licenses that make clear at the outset that a copyright owner will not be entitled to an injunction. Some of those statutes provide that a court or an administrative law judge will set the royalty rate in a particular case. ${ }^{70}$ Others delegate to an administrative law judge (specifically, to Copyright Royalty Judges) ${ }^{71}$ the power to set general license fees that apply to an entire industry. ${ }^{72}$ Finally, some provisions of the

67. See, e.g., Gregory N. Mandel, Promoting Environmental Innovation with Intellectual Property Innovation: A New Basis for Patent Rewards, 24 TEMP. J. SCI., TECH. \& ENVT'L L. 51, 60 (2005) (Clean Air Act provisions have never been used); Janice M. Mueller, No "Dilettante Affair": Rethinking the Experimental Use Exception to Patent Infringement for Biomedical Research Tools, 76 WASH. L. REV. 1, 51 n.253 (2001) (march-in rights have never been used).

68. Matthew Herper, Cipro, Anthrax and the Perils of Patents, FORBES (Oct. 17, 2001, 5:13 PM), http://www forbes.com/2001/10/17/1017cipro html.

69. See Lars Noah, Triage in the Nation's Medicine Cabinet: The Puzzling Scarcity of Vaccines and Other Drugs, 54 S.C. L. REV. 371 (2002).

70. This is true of disputes over the royalty due for broadcast retransmissions under 17 U.S.C. $\S 111(d)(4)(A)$ (2006), for example, and of licenses for public performances of musical works by jukeboxes, 17 U.S.C. § 116(b)(2).

71. Id. $\S 801$.

72. Id. §§ 112(e), 114(f), 118(b)(4), 119(c)(1)(F). 
copyright statute actually set the royalty rate in the statute, or establish rulemaking proceedings that preannounce the required royalty for a particular use. $^{73}$ The evidence shows that parties bargain around each of these three liability rules of copyright law.

\section{Settling Liability Rule Cases}

The first category involves uncertainty as to the amount of the license fee, and settlements in those cases take much the same form as settlements of NPE cases in patent law: the parties don't know who will win, or what the royalty will be if the plaintiff wins, but they know there won't be an injunction. The issue here is similar to the issue in patent cases when an injunction is unavailable, except that the parties know in advance that they are fighting over royalties rather than an injunction. In addition, the royalties are generally set by private arbitration or by a hearing before a Copyright Royalty Judge, rather than in court. As a result, there is not an authoritative source on the number of cases filed and then settled without a decision. Nonetheless, what evidence there is suggests that resort to these administrative courts is rare; the parties usually settle. $^{74}$

One piece of evidence comes from a different sort of litigation: antitrust consent decrees relating to collective owners of patents or copyrights. In a recent study, Daniel Crane looked at fifty-two antitrust consent decrees that gave the court continuing power to require IP owners to license their rights on reasonable and nondiscriminatory terms. ${ }^{75}$ He found that courts actually had to set the rate in only three of the fifty-two cases; in the rest, the parties bargained in the shadow of a court-imposed liability rule. ${ }^{76}$

\section{Collective Rights Organizations and Rate Rulemaking}

In the second set of cases, parties litigate to set the rate to govern a particular period. Nonetheless, the evidence suggests that the parties often agree to a rate on their own without waiting for a ruling from the Copyright Royalty Judge. One example is section 114 of the Copyright Act, which requires the payment of royalties for the digital performance of sound recordings. ${ }^{77}$ The statute doesn't set out what the royalty should be for performing sound recordings via Internet radio stations like Pandora.

73. Id. §§ 111(d)(1)(B), 115.

74. Crane, Intellectual Liability, supra note 44, at 294-95.

75. Crane, Bargaining, supra note 44.

76. Id. at 312; Daniel A. Crane, Optimizing Private Antitrust Enforcement, 63 VAND. L. REV. 675 (2010); see also W. Michael Garner, United States v. ASCAP: The Licensing Provisions of the Amended Final Judgment of 1950, 23 BuLL. COPYRIGHT SOC’Y 119, 127-28 (1976) (noting that ratesetting requests were brought to court under the ASCAP consent decree, but always settled without a court ruling).

77. 17 U.S.C. § 114. 
Sometimes parties litigate this question; we have had rulemakings every two years to set the royalty rate. ${ }^{78}$ But the individual owners of sound recordingswhich include the four major record labels plus the various independents-do not bring that litigation. Rather, a collective organization represents all the individual owners as a single group. In 2000, shortly after the digital performance right in sound recordings was added to the statute, the myriad owners of sound recording copyrights created a collective rights organization called SoundExchange to negotiate on their behalf and administer and collect the new reasonable royalty. ${ }^{79}$ SoundExchange often settles with Internet radio stations without going through the rulemaking process, ${ }^{80}$ but even when it doesn't, the point is that the copyright owners acted collectively to create a rights management organization very similar to ASCAP and BMI. It was the creation of a legal right, not the creation of a property rule to enforce that right, that drove the founding of collective rights organizations to administer public performance rights.

\section{Negotiating Around Fixed Prices}

Finally, and perhaps more surprisingly, we see bargaining even around the last set of rules - those that fix the price up front. When the law not only sets out the scope of the right but specifies the fee that will be paid, one might reasonably think there is nothing to bargain over. But there is, as the following examples show.

\section{a. Song Covers}

Want to cover a song that has been released by the copyright owner? The law permits it, and specifies the fee you must pay to do so. ${ }^{81}$ But parties often negotiate different rates than the set fee established by law. The cover license royalty rate started at $\$ 0.0275$ per song, ${ }^{82}$ and has been modified by Copyright Royalty Judges on several occasions as a result of Mechanical Rate Adjustment Proceedings provided for in the statute or to cover cost-of-living adjustments.

78. See, e.g., In re Digital Performance Right in Sound Recordings and Ephemeral Recordings, No. 2005-1CRB DTRA (Copyright Royalty Bd. 2007), available at http://www.loc.gov/crb/ proceedings/2005-1/rates-terms2005-1.pdf (order on 2005 rate setting proceeding); Beethoven.com L.L.C. v. Librarian of Cong., 394 F.3d 939 (D.C. Cir. 2005). For a summary of all the rates set by Copyright Royalty Judges since 1998, see Andrew Stockment, Note, Internet Radio: The Case for a Technology Neutral Royalty Standard, 95 VA. L. REV. 2129 app. (2009).

79. For a discussion of the history of SoundExchange, which was created to administer the new right added to 17 U.S.C. § 106(6) in 1995, see General Questions, SoundExCHANGE, http:// soundexchange.com/category/faq/\#question-432 (last visited Dec. 21, 2011).

80. Similarly, Crane reports that since Copyright Royalty Judges were given the power to set rates under section 112 (e) in 1976, they have only had to set a rate three times. Crane, Intellectual Liability, supra note 44, at 294-95 \& n.247.

81. 17 U.S.C. $\S 115$.

82. Id. § 115(c)(2). 
The current rate is $\$ 0.091$ per song. ${ }^{83}$ Those modifications were preceded by negotiations between relevant interest groups on both sides, negotiations that led to an agreement among repeat players to pay a higher rate than the law initially required. ${ }^{84}$

But even those negotiated flat rates aren't the end of the story. Copyright owners and the artists recording songs regularly agree to vary the 9.1-cent royalty provided for in the statute. The Harry Fox Agency, for instance, negotiates bulk deals for 25 percent less than the statutory rate. They do so for several reasons. Sometimes bargaining is easier than complying with the Copyright Office rules. Sometimes the parties are already participants in an ongoing relationship, and the fee is negotiated as a part of that relationship. That is true, for instance, when the recording artist is also the songwriter and, as part of the recording contract, agrees to cap the mechanical royalties. This is known as a "controlled composition" clause. Record companies employing such clauses worry that artists will put too many songs on an album, raising the royalty payment rate, so they may negotiate both a three-fourths rate and a fixed number of songs per album. Finally, where record producers have a variety of songs from which to choose (in compiling, say, a CD of hits from the 1980s), the presence of competition from other artists can drive the price down. We also see reduced rates where the purpose of the work is promotional (giving away music with the purchase of a full tank of gas, for instance) rather than profit maximizing, so that a full royalty may make the project uneconomical. ${ }^{85}$

The lesson here is remarkable: even when the liability remedy is clear, so that no one need worry whether a judge or jury will get it right, parties will sometimes bargain around a price they consider inefficient, particularly if they are in an existing relationship or if there are competitive alternatives. It is worth noting, however, that the compulsory license rate seems to have somewhat of an anchoring effect. Rather than negotiate numbers from scratch, record companies tend to negotiate rates set as a percentage of the statutory rate (such as a three-fourths rate).

\section{b. Cable Retransmission}

A second example of negotiating around fixed prices involves cable retransmission of broadcast television signals. Section 111 of the Copyright Act provides that cable operators can carry broadcast television signals if they pay a

83. The rate history is discussed at Mechanical License Royalty Rates, U.S. COPYRIGHT OFFICE (Oct. 18, 2010), http://www.copyright.gov/carp/m200a.html.

84. For discussion of one example, the 2001 agreement, see Section 115 Hearings, supra note 10, at 11-13, available at http://www.copyright.gov/docs/regstat031104 html (prepared statement of Marybeth Peters, Register of Copyrights).

85. I am grateful to Cary Sherman and Paul Goldstein for discussing the business of music licensing with me. Some of the information in this paragraph comes from those conversations. 
fee set by the Act; the calculation of the fee itself is rather complicated. ${ }^{86}$ Cable television stations pay royalties under those fees. But those royalties have declined even as the revenues of cable companies have increased. ${ }^{87}$ Part of the reason for the decline is that broadcast television signals are less important to cable networks than they were thirty years ago, as cable programming has come into its own. But the other reason is that broadcasters and cable operators started their own private negotiations in lieu of the compulsory license. ${ }^{88}$ Congress endorsed this private negotiation alternative in $1992,{ }^{89}$ but it is worth noting that congressional action to modify the compulsory license followed private bargaining rather than drove it. ${ }^{90}$

\section{c. Zero-Price Liability Rules}

A third example of bargaining around fixed prices involves what are sometimes called zero-price liability rules. ${ }^{91}$ These are more commonly thought of as exemptions from, or defenses to, copyright liability. They permit the defendant to act, imposing neither an injunction nor damages liability. At the same time, they are not property rules that vest in copyright defendants the right to stop interference with the exercise of the right. The first-sale doctrine is an example of a zero-price liability rule. Purchasers of copyrighted works are entitled to resell, rent, or give them away without liability to the copyright owner. $^{92}$ That right can be amended by contract, however, ${ }^{93}$ and there is no property rule vested in buyers that prevents the copyright owner from interfering with first-sale rights (for example by imposing technical restrictions on the use or resale of a copyrighted product). ${ }^{94}$

86. 17 U.S.C. $§ 111$.

87. Botein \& Samuels, supra note 10, at 76, 85 graph I, 86 graph II (showing a peak of \$200 million in royalties in 1989 , falling to $\$ 120$ million by the turn of the millennium).

88. See U.S. REGISTER OF COPYRIGHTS, THE CABLE AND SATELLITE CARRIER COMPULSORY LICENSES: AN OVERVIEW AND ANALYSIS app. B at 19 (1992), available at http://www. copyright.gov/reports/cable-sat-licenses1992.pdf.

89. 47 U.S.C. $\S 325$ (b) (1994), added as part of the Communications Act in 1992. Cable Television Consumer Protection and Competition Act of 1992, Pub. L. No. 102-385, § 6, 106 Stat 1482.

90. For a discussion of the history and the evidence on these negotiations, see Botein \& Samuels, supra note 10, at 78-80. Thanks to Preston Padden for discussion of this history.

91. Lemley \& Weiser, supra note 5; see also C. Scott Hemphill, Network Neutrality and the False Promise of Zero-Price Regulation, 25 YALE J. ON REG. 135 (2008); Timothy J. Brennan, Copyright, Property, and the Right to Deny, 68 CHI.-KENT L. REV. 675, 712 (1993).

92. 17 U.S.C. $\S 109(a)$ (2006).

93. Vernor v. Autodesk, Inc., 621 F.3d 1102 (9th Cir. 2010). But cf. UMG Recordings, Inc. v. Augusto, 628 F.3d 1175 (9th Cir. 2011) ("label license” did not constitute such a contract banning first sale).

94. For instance, copyright owners could encrypt their data and permit decryption only a limited number of times. They could limit the devices that can play the work, as the DVD Copy Control Association does, or they could cause the work to expire after a certain period of time. 
Copyright owners regularly bargain around the first-sale doctrine and other limitations on the scope of copyright. Copyright owners who have the bargaining power to force buyers to adhere to standard form licenses regularly impose restrictions on use and resale. For example, virtually all software vendors attempt to restrict reverse engineering and often purport to limit the ability of the purchaser to transfer the software, even in conjunction with the sale of a computer on which it has been loaded. ${ }^{95}$ And these contracts have expanded from software into all walks of life as the Internet has made possible ubiquitous terms of use in online interaction. ${ }^{96}$

Perhaps those "bargains" shouldn't count because they depend on the inability of one side to negotiate, and often even to read, the agreement they are entering into. ${ }^{97}$ But even sophisticated parties negotiate around the first-sale doctrine. For example, video rental stores do not need a license from the copyright owner to rent the videos they purchase to the public. ${ }^{98}$ Copyright owners tried to shut down video players altogether, but they failed. ${ }^{99}$ Once those copyright owners began to discover that there was a market for selling videos for use in those players, stores like Blockbuster began buying the videos and renting them to customers. Copyright owners objected to this because they felt that they were losing sales to customers, but the first-sale doctrine meant that they had no legal right to prevent it. They responded in the 1980s by raising the price of newly-released videos, sometimes charging over $\$ 100$ for a video in the first weeks of release. ${ }^{100}$ This was a form of price discrimination, since video stores needed to be able to offer videos as early as possible. It allowed copyright owners to capture some of the higher value that video stores get from videos compared to individual buyers.

But then an interesting thing happened: the copyright owners and the video stores entered into agreements to license copyrighted works for which the stores didn't actually need a license. Today, all the major DVD rental services (Blockbuster, Netflix, Redbox) appear to have entered into agreements with all the major movie studios governing the release of their DVDs. ${ }^{101}$ The details of

95. Among many discussions of these issues, see Nancy S. Kim, Clicking and Cringing, 86 OR. L. REV. 797 (2007); Mark A. Lemley, Beyond Preemption: The Law and Policy of Intellectual Property Licensing, 87 CALIF. L. REV. 111 (1999); Mark A. Lemley, Intellectual Property and Shrinkwrap Licenses, 68 S. CAL. L. REV. 1239 (1995) [hereinafter Lemley, Shrinkwrap Licenses].

96. See Mark A. Lemley, Terms of Use, 91 MinN. L. REV. 459 (2006).

97. Lemley, Shrinkwrap Licenses, supra note 95, at 1252 (expressing this concern).

98. 17 U.S.C. § 109(a) (2006).

99. See Sony Corp. of Am. v. Universal City Studios, Inc., 464 U.S. 417 (1984); Columbia Pictures Indus., Inc. v. Prof'l Real Estate Investors, Inc., 866 F.2d 278 (9th Cir. 1989).

100. For discussion of the economics of traditional (i.e., pre-revenue-sharing) video rentals, see Julie Niederhoff, Video Rental Developments and the Supply Chain: Netflix, Inc. (undated business case study), available at http://apps.olin.wustl.edu/workingpapers/pdf/2004-03-225.pdf.

101. Redbox entered into a deal with several studios. Brooks Barnes, Movie Studios See a Threat in Growth of Redbox, N.Y. TIMES (Sept. 6, 2009), http://www nytimes.com/2009/09/07/ business/media/07redbox html. Redbox filed an antitrust suit against other studios when they 
these agreements vary, but rental services appear to get access to cheap DVDs in exchange for some combination of revenue sharing or an agreement to delay release of the DVD until a certain date. ${ }^{102}$

We have seen other examples of voluntary contracting around zero-price liability rules in copyright and trademark law. A number of Internet intermediaries, including YouTube, have voluntarily adopted proactive programs to identify and remove infringing content from their systems, despite the fact that the Digital Millennium Copyright Act gives them immunity from liability as long as they properly respond to takedown notices. ${ }^{103}$ YouTube's Content ID system identifies potentially infringing content on its site and offers the copyright owner the option of removing it, leaving it up, or "claiming" it and sharing in advertising revenue from the site. ${ }^{104}$ eBay voluntarily implements a Verified Rights Owner program that works with copyright and trademark owners to identify and eliminate auctions over counterfeit goods, despite the presence of a safe harbor in trademark law. ${ }^{105}$ And a group of Internet service providers recently agreed with copyright owners to implement a graduated response to complaints of infringement, including notification of alleged infringers, education, and sanctions for repeat infringers. ${ }^{106}$

To be sure, copyright and trademark owners have aggressively tried to create uncertainty about the scope of the copyright and trademark safe harbors, though to date those efforts have been unavailing. ${ }^{107}$ It may be that the threat of liability drove some of these efforts; certainly, proactive efforts at weeding out infringement put Internet intermediaries in a better atmospheric position in

collectively refused to sell to it for four weeks after a release; the parties settled the case with the twenty-eight-day delay intact. See Ben Fritz, Redbox Agrees to 28-Day Delay in Offering Warner Movies, L.A. TIMES (Feb. 17, 2010), http://articles.latimes.com/2010/feb/17/business/la-fi-ctredbox17-2010feb17; Tom Hals \& Sue Zeidler, Update 3-Redbox Sues 20th Century Fox over DVD Rentals, REUTERS (Aug. 12, 2009, 3:13 PM), http:/www reuters.com/article/2009/08/12/redboxnewscorp-idUSN1211720620090812. Netflix entered into revenue-sharing agreements in which it obtains DVDs at cost but shares its revenue with the studios. Netflix Pays a Revenue Share on About Half of Rentals, HACKINGNETFLIX (Sept. 18, 2009), http://www hackingnetflix.com/2009/09/netflixpays-a-revenue-share-on-about-half-of-rentals html. Blockbuster did the same. See Georg Szalai, Lionsgate Says Dish's Blockbuster Owes it Money Under Revenue Share Deal, HoLLYWOOD REP. (Apr. 29, 2011, 8:34 AM), http://www hollywoodreporter.com/news/lionsgate-says-dishs-blockbusterowes-183689.

102. Niederhoff, supra note 100 .

103. 17 U.S.C. § 512 (2006).

104. Content ID, YOUTUBE, http://www.youtube.com/t/contentid (last visited Dec. 21, 2011).

105. 15 U.S.C. $\S 1114(2)(B)-(C)$ (2000).

106. Nate Anderson, Major ISPs Agree to "Six-Strikes" Copyright Enforcement Plan, ARS TECHNICA, http://arstechnica.com/tech-policy/news/2011/07/major-isps-agree-to-six-strikes-copyright -enforcement-plan.ars (last visited Dec. 21, 2011).

107. Tiffany Inc. v. eBay Inc., 600 F.3d 93 (2d Cir. 2010); Viacom Int’l Inc. v. YouTube, Inc., 718 F. Supp. 2d 514 (S.D.N.Y. 2010); UMG Recordings, Inc. v. Veoh Networks Inc., 665 F. Supp. 2d 1099 (C.D. Cal. 2009). 
defending these lawsuits. ${ }^{108}$ But large technology companies also have interests in establishing relationships with rights owners even in the absence of a legal obligation to do so. YouTube, for instance, has been able to convert some infringing videos into authorized postings for which YouTube and the copyright owner split the advertising revenue. ${ }^{109}$

The fact that buyers will contract with copyright owners even when they don't have to-when the law gives them the right to use the work without payment, or on payment of a set fee-is perhaps the most powerful evidence yet that intellectual property owners contract around liability as well as property rules. It also undermines an objection, sometimes heard, that parties facing a license fee may agree to a lower price but never to a higher one. ${ }^{110}$ Prices in copyright cases can move in any direction from the liability rule norm. Indeed, some of the examples, such as no-reverse-engineering clauses or noscraping clauses on websites, are at least efforts to agree to a property rule to be enforced by specific performance. They thus represent efforts to bargain around a liability rule in the truest sense: the parties agree to substitute a property rule for the default legal entitlement.

In sum, there are at least three forms of fixed-price liability rules in copyright law: the cover license royalty set by Copyright Royalty Judges, section 111's set fee for cable broadcasts carrying broadcast television signals, and rules, such as the first-sale doctrine, that automatically set the price at zero. But the evidence shows that parties frequently choose to contract around these liability rules, rather than seek to enforce the prices fixed by the rules to the hilt.

III.

IMPLICATIONS FOR THE DEBATE OVER PROPERTY RULES AND LIABILITY RULES

Showing that parties contract around liability as well as property rules in IP cases does not, standing alone, make a case for liability rules. ${ }^{111}$ Rather, the evidence I discuss in this Essay is more precisely understood as undermining one common argument for the superiority of property over liability rules. Merges has said that "[c]ompulsory licensing is far inferior to private bargain-

108. In Tiffany v. eBay, for instance, the court discussed at great length eBay's efforts to prevent counterfeit goods from being sold on its site. 600 F.3d at 98-100. And the Digital Millennium Copyright Act (DMCA) safe harbor statute requires Internet service providers (ISPs) to implement a policy to terminate repeat infringers, 17 U.S.C. § 512(i)(1)(A); their recent deal with copyright owners may accomplish that goal.

109. Content ID, supra note 104.

110. Epstein, Clear View, supra note 17 (arguing that compulsory licenses serve as a price ceiling).

111. Jerry Reichman is perhaps the leading U.S. advocate for compulsory licenses in IP. See, e.g., J.H. Reichman, Of Green Tulips and Legal Kudzu: Repackaging Rights in Subpatentable Innovation, 53 VAND. L. REV. 1743, 1776-97 (2000); Reichman \& Lewis, supra note 12. 
ing as a way to set prices for IP content."112 But as I have shown in this Essay, that is a false dichotomy. The choice is not between court-set liability rules and private bargaining around property rules; parties are just as likely to bargain around compulsory licenses.

The invalidity of that argument does have important implications for the overall debate over property rules versus liability rules. If the parties to a lawsuit cannot come to an agreement (the only circumstance in which cases will get decided), liability rules generally permit greater accuracy than property rules. Property rules are all-or-nothing results; they don't allow the sorts of tailoring that liability rules do. In other words, a property rule sacrifices the potential accuracy of liability rules in the hopes of creating better ex ante incentives. If we don't have reason to believe that the property rule will increase agreements, the case for property over liability rules is weakened substantially.

Those who favor property over liability rules also argue that district courts and juries will get liability rules wrong. Sometimes this is a complaint about accuracy, though, as noted above, even random errors in setting liability rules are likely to produce more accuracy than actually enforcing a property rule without bargaining. ${ }^{113}$ But property-rule advocates also argue that liability rules will be systematically biased relative to property rules. Generally, this is a claim that liability rules are systematically biased to undercompensate IP owners. $^{114}$

I confess that I am skeptical of the claim of undercompensation as an inherent feature of liability rules; it may well be that what property-rule advocates call bias is in fact the elimination of overcompensation resulting from the holdup property rules make possible. ${ }^{115}$ Resolving that debate is not

112. Robert P. Merges, The Continuing Vitality of Music Performance Rights Organizations 4 (June 11, 2008) (unpublished manuscript), available at http://escholarship.org/uc/item/7cf864x2.

113. In any event, inaccuracy can actually generate bargaining, as Daniel Crane points out. Crane, Intellectual Liability, supra note 44, at 293.

114. See, e.g., Einer Elhauge, Do Patent Holdup and Royalty Stacking Lead to Systematically Excessive Royalties?, 4 J. COMPETITION L. \& ECON. 535, 557 (2008); Epstein, Clear View, supra note 17; Epstein \& Kieff, supra note 5, at 80; John M. Golden, Intellectual Liability in Context, 88 TEX. L. REV. 211, 217 (2010); John M. Golden, Principles for Patent Remedies, 88 TEX. L. REV. 505, 568-69 (2010), http://www.texaslrev.com/sites/ default/files/seealso/vol88/pdf/88TexasLRevSeeAlso211.pdf. Golden and Elhauge both make the critical assumption that parties will never bargain for more than the liability rule price. As the evidence in this article shows, that is not true.

115. See Lemley \& Shapiro, supra note 14; Lemley \& Weiser, supra note 5. See also Crane, Intellectual Liability, supra note 44, at 294.

On the other hand, sometimes the explicit goal of a liability rule is to eliminate the supracompetitive price associated with the exclusivity an IP right provides. See Epstein \& Kieff, supra note 5, at 72 (making the case that this is true of pharmaceutical compulsory licenses in the developing world); Keith E. Maskus, Ensuring Access to Essential Medicines: Some Economic Considerations, 20 WIS. INT'L L.J. 563, 572-73 (2002) (compulsory licensing fees tend to be set low). In that case a liability rule compensates less than a property rule would. Whether that is a problem for innovation, however, is debatable. See, e.g., Petra Moser \& Alessandra Voena, Compulsory Licensing: Evidence 
my goal in this Essay. Nonetheless, evidence that parties contract around liability as well as property rules affects the undercompensation argument as well. If parties can and do freely contract around liability as well as property rules, raising the price when it is appropriate, it might not matter whether liability rules undercompensate, just as it shouldn't matter whether property rules promote holdup if the parties agree to avoid that holdup.

The choice between property rules and liability rules may still have an effect, however. Setting the default legal entitlement may have the effect of anchoring negotiations, and may therefore influence the price set in the ultimate bargain. We have seen that parties will sometimes contract even around a set price, but the fact that the price has been set may affect what the parties agree to. John Golden, for instance, worries that "private bargaining in the shadow of an error-prone liability regime is not necessarily socially optimal bargaining.”" ${ }^{116}$ But all advantages are comparative. Injunctions are rarely the "right" outcome in a patent or copyright case; there are often deals to be made. The case for the superiority of property rules depends on the ability of parties to bargain from a bad legal outcome to a better one. And if that bargaining can occur around liability as well as property rules, there is no reason to think the bargaining will somehow be qualitatively worse than it is around property rules.

While bargaining will still occur, the baseline may still affect the outcome. Traditional law and economics theory assumes that people freely contract around default rules. But in fact they may take the nominal legal default as a normative entitlement and be reluctant to disturb it. Behavioral law and economics has shown abundant evidence of such an endowment effect. ${ }^{117}$ If so, the setting of the initial legal entitlement will matter even if we expect the parties to contract around that rule, since setting the rule will determine whether IP owners get paid a lot or a little. Whether this fact supports a liability or a property rule depends in the first instance on whether we think the risk of holdup from property rules is greater or less than the putative risk of systematic undercompensation from liability rules.

But there may be a second-order effect. It may be that giving property rule entitlements creates a stronger endowment effect than would a liability rule. ${ }^{118}$ If in fact people are more reluctant to part with something they think of as

From the Trading with the Enemy Act (Nat'l Bureau of Econ. Research, Working Paper No. 15598, 2009), available at http://www nber.org/papers/w15598.pdf (finding that compulsory licensing supports domestic innovation).

116. Golden, Intellectual Liability in Context, supra note 114, at 217.

117. See, e.g., Russell Korobkin, The Endowment Effect and Legal Analysis, 97 NW. U. L. REV. 1227 (2007); Russell Korobkin \& Chris Guthrie, Heuristics and Biases at the Bargaining Table, 87 MARQ. L. REV. 795, 803 (2004); Shmuel I. Becher \& Tal Z. Zarsky, Open Doors, Trap Doors, and the Law, LAW \& CONTEMP. PROBS., Spring 2011, at 63, 77-80.

118. See, e.g., Jeffrey J. Rachlinski \& Forest Jourden, Remedies and the Psychology of Ownership, 51 VAND. L. REV. 1541 (1998). 
"theirs," and treating it as property creates that perception, but merely giving a right to sue for damages does not, property rules may actually interfere with transactions in a way liability rules do not. ${ }^{119}$ Christopher Buccafusco and Christopher Sprigman have demonstrated that the endowment effect works in intellectual property, and that there is a still-stronger "creativity effect" that makes creators reluctant to part with their works for what an outsider would describe as fair market value. ${ }^{120}$ Unlike the endowment effect, this creativity effect is asymmetric, since it vests only in creators. If this proves true, it suggests that property rules are likely to overcompensate IP owners or, failing that, to prevent efficient transactions.

Because IP rights represent a government intervention in the marketplace designed to encourage new inventions and creations, society has an interest in how much IP owners get paid. ${ }^{121}$ As a result, if we think the initial legal entitlement does affect the outcome of bargaining, we may have to resolve the holdup versus undercompensation debate. I don't intend to do more here than start that discussion and suggest that it is more complicated than advocates of property rules would suggest.

What should be clear from the evidence is that parties contract around liability rules as well as property rules. As a result, the possibility of contracting around property rules can't itself support injunctions in IP cases. The evidence from liability rules gives us a more nuanced picture of how entitlements play out in the real world. And that more nuanced picture makes a stronger case for liability rules than one would have thought possible after reading Merges's seminal article.

119. Christine Jolls \& Cass R. Sunstein, Debiasing Through Law, 35 J. LEGAL STUD. 199, 220-22 (2006); Ayres \& Talley, supra note 7, at 1101-02.

120. Christopher Buccafusco \& Christopher Jon Sprigman, The Creativity Effect, 78 U. CHI. L. REV. 31 (2011); Christopher Buccafusco \& Christopher Sprigman, Valuing Intellectual Property: An Experiment, 96 CORNELL L. REV. 1 (2010).

121. See, e.g., Brett M. Frischmann \& Mark A. Lemley, Spillovers, 107 COLUM. L. REV. 257 (2007); Mark A. Lemley, Property, Intellectual Property, and Free Riding, 83 TEX. L. REV. 1031 (2005). 